\title{
Distributions and stoichiometry of dissolved nitrogen and phosphorus in the iron-fertilized region near Kerguelen (Southern Ocean)
}

\author{
S. Blain ${ }^{1,2}$, J. Capparos ${ }^{1,2}$, A. Guéneuguès ${ }^{1,2}$, I. Obernosterer ${ }^{1,2}$, and L. Oriol ${ }^{1,2}$ \\ ${ }^{1}$ Sorbonne Universités, UPMC Univ Paris 06, UMR7621, Laboratoire d'Océanographie Microbienne, Observatoire \\ Océanologique, 66650 Banyuls/mer, France \\ ${ }^{2}$ CNRS, UMR7621, Laboratoire d'Océanographie Microbienne, Observatoire Océanologique, 66650 Banyuls/mer, France \\ Correspondence to: S. Blain (stephane.blain@obs-banyuls.fr)
}

Received: 13 June 2014 - Published in Biogeosciences Discuss.: 27 June 2014

Revised: 9 December 2014 - Accepted: 16 December 2014 - Published: 30 January 2015

\begin{abstract}
During KEOPS2 (Kerguelen Ocean and Plateau Compared Study 2), we determined dissolved inorganic and organic nitrogen and phosphorus species in the naturally fertilized region of Kerguelen Island (Southern Ocean). Above $150 \mathrm{~m}$, stations were clearly separated by the polar front $(\mathrm{PF})$, with concentrations of $\mathrm{NO}_{3}^{-}, \mathrm{NO}_{2}^{-}$and $\mathrm{PO}_{4}^{3-}$ overall lower north of the PF than south. Though less pronounced, a similar trend was detectable for dissolved organic nitrogen (DON) and dissolved organic phosphorus (DOP). At all stations offshore and above the plateau, a subsurface maximum of $\mathrm{NH}_{4}^{+}$was observed between 50 and $150 \mathrm{~m}$. We examined nutrient stoichiometry by calculating the linear combination $N^{*}=\left[\mathrm{NO}_{3}^{-}\right]-16\left[\mathrm{PO}_{4}^{3-}\right]$. The majority of stations and depths revealed $N^{*}$ close to $-3 \mu \mathrm{M}$; however, for surface waters north of the PF, $N^{*}$ increased up to $6 \mu \mathrm{M}$. This suggests a preferential uptake of $\mathrm{PO}_{4}^{3-}$ versus $\mathrm{NO}_{3}^{-}$by fastgrowing diatoms. Using the tracer $\mathrm{TN}_{\mathrm{xs}}=$ [TDN]-16[TDP] (TDN, total dissolved nitrogen; TDP, total dissolved phosphorus) revealed that the dissolved organic fraction significantly contributed to changes in $\mathrm{TN}_{\mathrm{xs}}$. $\mathrm{TN}_{\mathrm{xs}}$ values were negative for most stations and depths, and relatively constant in the $0-500 \mathrm{~m}$ layer. As for $N^{*}$, the stations north of the PF had higher $\mathrm{TN}_{\mathrm{xs}}$ in the 0-100 m layer. We discuss this stoichiometric anomaly with respect to possible external sources and sinks of $\mathrm{N}$ and $\mathrm{P}$. Additional data collected in February 2013 at two sites revealed the occurrence of a subsurface minimum of $N^{*}$ located just below the pycnocline, which denotes a layer where remineralization of particulate organic matter with low $\mathrm{N}$ : $\mathrm{P}$ ratio $\mathrm{P}$, possibly associated with preferential remineralization of $\mathrm{P}$ versus $\mathrm{N}$, persists throughout the season.
\end{abstract}

\section{Introduction}

The first scientific expeditions in the Southern Ocean discovered high concentrations of major nutrients such as nitrate $\left(\mathrm{NO}_{3}^{-}\right)$and phosphate $\left(\mathrm{PO}_{4}^{3-}\right)$ in surface waters south of $50^{\circ} \mathrm{S}$ (Hart, 1942). The general meridional overturning circulation that brings deep water to the surface at the southern limits of the Antarctic Circumpolar Current (Marshall and Speer, 2012) is the major mechanism supplying surface waters with $\mathrm{NO}_{3}^{-}$and $\mathrm{PO}_{4}^{3-}$. Most of the nutrient-rich upwelled waters are transported northward and they leave the surface north of the polar front through their transformation into intermediate and mode waters. Despite the several-monthlong northward transport during which the $\mathrm{NO}_{3}^{-}$- and $\mathrm{PO}_{4}^{3-}$ rich waters are exposed to sunlight, not much phytoplankton biomass develops. This system was characterized as highnitrate low-chlorophyll (HNLC). The major consequence of the HNLC status of the Southern Ocean is that large amounts of unused nutrients are transported back into the ocean interior where they feed the main thermocline and finally supply low- and mid-latitude surface waters with essential nutrients (Sarmiento et al., 2004). Another consequence is that similarly to $\mathrm{NO}_{3}^{-}$and $\mathrm{PO}_{4}^{3-}$, large amounts of upwelled dissolved inorganic carbon (DIC) are not converted to particulate organic carbon (POC) and remain in contact with the atmosphere for time periods long enough to degas carbon dioxide $\left(\mathrm{CO}_{2}\right)$ with important consequences for climate (Sigman and Boyle, 2000).

The iron hypothesis (Martin and Fitzwater, 1988) was a major advancement for our understanding of the HNLC paradox. More than 2 decades of intense research have confirmed 


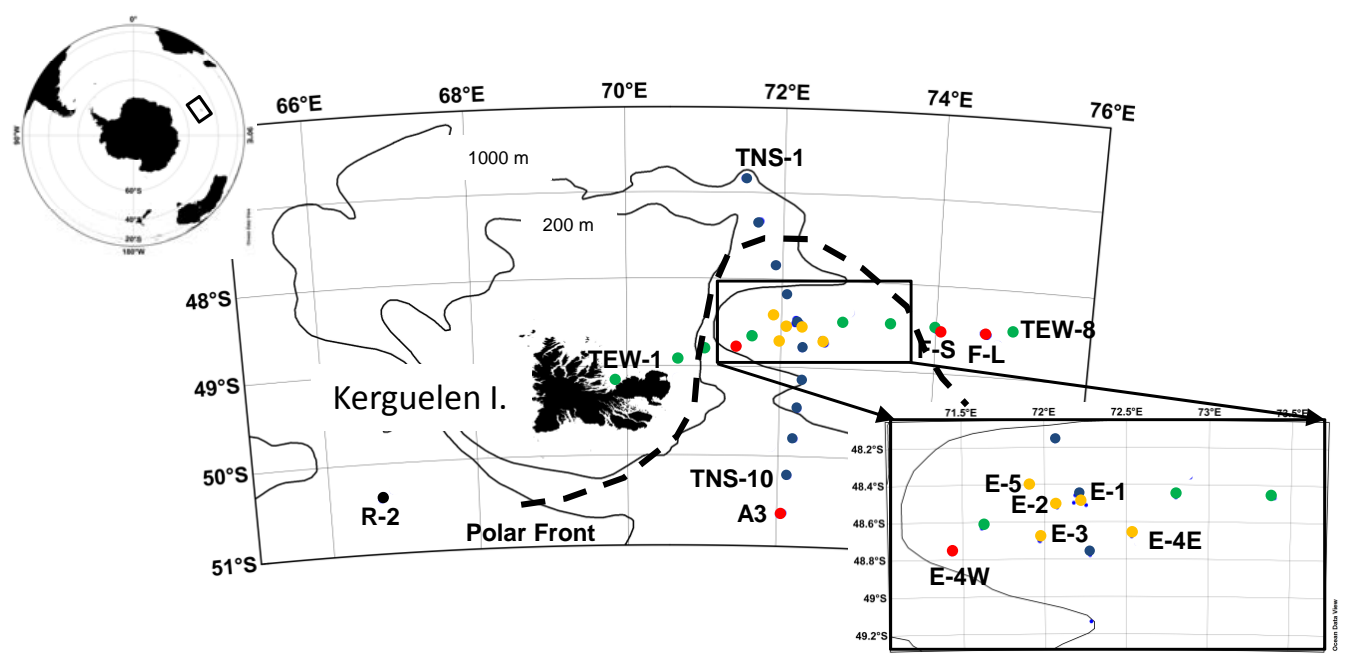

Figure 1. Map of the KEOPS2 study area. The locations of the stations are marked by colored dots. Blue indicates the stations of the northsouth transect (TNS), green indicates the stations of the east-west transect (TEW), orange indicates the stations E located in the meander of the polar front (zoom panel). Red shows other stations located in the fertilized region and black shows the station located in the high-nitrate low-chlorophyll (HNLC) region. Detailed positions of the stations are given in Table S1.

that increasing iron supply stimulates primary production, major nutrient utilization and the air-to-sea flux of $\mathrm{CO}_{2}$ in surface waters. Nutrient utilization in surface waters is therefore a diagnostic of the efficiency of the biological pump of $\mathrm{CO}_{2}$. Nitrate utilization has also received much attention in paleoceanographic studies, because it can be inferred from the isotopic composition of $\mathrm{N}$ in bulk material or specific compounds of fossil organisms preserved in the sediment. Recent results provide support to the enhanced $\mathrm{NO}_{3}^{-}$utilization related to higher dust deposition during the ice ages in the sub-Antarctic region (Martinez-Garcia et al., 2014).

Early modeling studies on the iron hypothesis were conducted using models that did not explicitly represent the iron cycle. The effect of iron fertilization was mimicked using the extreme assumption that iron fertilization results in the complete depletion of N or P in surface waters (Gnanadesikan et al., 2003; Sarmiento and Orr, 1991). However, this was never observed during artificial iron fertilization (Boyd et al., 2007), iron addition during deck incubations (Moore et al., 2007) or in naturally iron-fertilized regions (Blain et al., 2007). For most previous research in this context, it was assumed that $\mathrm{NO}_{3}^{-}$and $\mathrm{PO}_{4}^{3-}$ behave in a similar way. This is only true at first glance as interesting differences have been noticed (Jenkins et al., 1984; Minas and Minas, 1992; Lourey and Trull, 2001). Weber and Deutsch (2010) used zonal mean distributions of $\mathrm{NO}_{3}^{-}$and $\mathrm{PO}_{4}^{3-}$ in the Southern Ocean to reveal that the differential utilization of both nutrients is likely related to the composition of the phytoplankton community. Detailed investigations of blooms in varying regions of the Southern Ocean confirm different utilization of $\mathrm{NO}_{3}^{-}$and $\mathrm{PO}_{4}^{3-}$ depending on the dominant species in the phytoplankton community (Arrigo, 1999; De Baar et al., 1997; Moore et al., 2007). In addition, the possible role of dissolved organic nitrogen (DON) and dissolved organic phosphorus (DOP) for $\mathrm{N}$ and $\mathrm{P}$ decoupling has not been investigated, although modeling studies suggest that these organic forms may significantly contribute to the cycling of $\mathrm{N}$ and $\mathrm{P}$ in the Southern Ocean (Wang et al., 2003).

Our work presents new data on dissolved inorganic and organic nitrogen and phosphorus concentrations from the ironfertilized regions near the Kerguelen archipelago. We present their spatial and temporal distributions, and discuss their stoichiometry.

\section{Material and methods}

\subsection{Sampling}

During KEOPS2 (Kerguelen Ocean and Plateau Compared Study 2), the samples were collected at the stations presented on the map in Fig. 1. The coordinates and date of sampling are summarized in Table S1. Additional samples were collected during the cruise KEOPSMOOR (Kerguelen Ocean and Plateau compared Study, Moorings) in February 2013 at stations A3 and at station TNS-6 (Table S1). The samples for dissolved nitrogen and phosphorus analyses were collected with twenty-two $12 \mathrm{~L}$ Niskin bottles mounted on a rosette equipped with a Seabird SBE911-plus CTD (conductivity, temperature and depth) unit. In this work, we used potential temperature $(\theta)$ and density anomaly $(\sigma)$ to characterize the hydrology of the stations. A more complete description of the hydrology and the circulation is presented in Park et al. (2014).

For $\mathrm{NO}_{3}^{-}, \mathrm{PO}_{4}^{3-}$ and nitrite $\left(\mathrm{NO}_{2}^{-}\right)$, syringes $(50 \mathrm{~mL})$ were directly connected to the spigot of the Niskin bottles. The 
samples were drawn through a $0.45 \mu \mathrm{m}$ Uptidisc (Whatman) adapted for the syringe. Duplicate samples were collected. The second sample $(25 \mathrm{~mL})$ was poisoned with mercuric chloride $\left(\mathrm{HgCl}_{2}, 20 \mathrm{mg} \mathrm{L}^{-1}\right.$, final concentration) and stored in the dark at room temperature for later analysis.

For ammonium $\left(\mathrm{NH}_{4}^{+}\right)$, samples were collected from Niskin bottles in two $50 \mathrm{~mL}$ Schott glass bottles. Following rinsing, the bottles were filled with $40 \mathrm{~mL}$ of seawater and closed immediately to avoid contamination by air. Back at the onboard laboratory, the oxidative reagent (Holmes et al., 1999) was added. Samples for $\mathrm{NH}_{4}^{+}$determination were incubated for at least $3 \mathrm{~h}$ in the dark, at ambient temperature, before fluorescence measurements $\left(\lambda_{\text {exc }}=370, \lambda_{\text {emi }}=\right.$ $460 \mathrm{~nm}$ ) with a fluorimeter (Jabsco).

For dissolved organic nitrogen (DON) and phosphorus (DOP) analysis the samples were collected from Niskin bottles in $100 \mathrm{~mL}$ Schott glass bottles. The Schott glass bottles were rinsed with $\mathrm{HCl}(10 \%)$ once and several times with ultrapure water (prepared by deionization and UV sterilization) between casts. The samples were then filtered through two combusted GF/F filters. $20 \mathrm{~mL}$ of the filtered samples were transferred to $20 \mathrm{~mL}$ PTFE vials and poisoned with $100 \mu \mathrm{l}$ of $\mathrm{HgCl}_{2}\left(4 \mathrm{~g} \mathrm{~L}^{-1}\right.$, working solution) before storage at $4{ }^{\circ} \mathrm{C}$. All analyses were performed aboard as described below.

\subsection{Analytical methods}

For $\mathrm{NO}_{3}^{-}, \mathrm{NO}_{2}^{-}, \mathrm{PO}_{4}^{3-}$, one sample was immediately analyzed aboard with a segmented flow analyzer (Skalar) equipped with colorimetric detection using methods described in (Aminot and Kérouel, 2007). The accuracy of the methods was assessed using reference material (Certipur, Merck). The precisions were in the range of $1-4 \%$, and the limit of detection was $0.02 \mu \mathrm{M}$ for $\mathrm{NO}_{3}^{-}$and $\mathrm{NO}_{2}^{-}$, and $0.03 \mu \mathrm{M}$ for $\mathrm{PO}_{4}^{3-}$.

Samples for DON and DOP determination were spiked with $2.5 \mathrm{~mL}$ of the oxidative reagent (boric acid + sodium hydroxide + potassium peroxodisulfate), and then heated at $120^{\circ} \mathrm{C}$ for $30 \mathrm{~min}$. After cooling, the concentrations of $\mathrm{NO}_{3}^{-}$ and $\mathrm{PO}_{4}^{3-}$ were determined as mentioned above. This provides the concentrations of total dissolved nitrogen (TDN) and total dissolved phosphorus (TDP). The concentrations of DON and DOP were calculated as follows; $\mathrm{DON}=\mathrm{TDN}$ $\left[\mathrm{NO}_{3}^{-}\right]-\left[\mathrm{NO}_{2}^{-}\right]$and $\mathrm{DOP}=\mathrm{TDP}-\left[\mathrm{PO}_{4}^{3-}\right]$.

\section{Results}

Most of the stations are located south of the polar front (PF), with the exception of the coastal stations TEW-1-2 and the offshore stations TNS-1-2, TEW-7-8 and F-L, which were located north of the PF (Fig. 1). Station R-2, located west of the plateau, had low chlorophyll concentrations in surface water throughout the season $\left(\sim 0.3 \mathrm{mg} \mathrm{m}^{-3}\right)$ (Lasbleiz et al., 2014), an observation that is explained by the low iron supply (Quéroué et al., 2015). In contrast, all other stations were characterized by the development of large spring blooms consistent with higher iron supply (Lasbleiz et al., 2014). However, the development of the blooms within the iron-fertilized region was not homogenous in time and space. A3-1 and stations TNS-1 to TNS-10 of the north-south transect, sampled at the beginning of the spring bloom, were characterized by low chlorophyll concentrations only slightly higher than that at station R-2. Stations TEW-1 to TEW-8 of the east-west transect, stations E-2 to E-5, and station A32 (the second visit to station A3), were sampled a few days later, when the bloom rapidly developed with large spatial heterogeneity. The largest stocks of chlorophyll $a$ within the 0-200 m layer were observed at stations F-L, north of the PF, and at station A3-2, above the plateau. Based on the trajectories of two surface drifters (Zhou et al., 2014), stations E-1, E-2, E-3, E4-E and E-5 are assumed to evolve in a quasiLagrangian framework, and their succession in time can be considered approximately as a time series.

\subsection{Two-dimensional distributions of dissolved nitrogen and phosphorus.}

In the upper $200 \mathrm{~m}$ of the water column, concentrations of $\mathrm{NO}_{3}^{-}$and $\mathrm{PO}_{4}^{3-}$ were $\geq 19$ and $\geq 1 \mu \mathrm{M}$, respectively (Figs. 2 and 3). Concentrations were higher west of the PF (transect E-W, Fig. 2) and south of the PF (transect N-S, Fig. 3) and lower in surface sub-Antarctic waters, north and east of the PF. Concentrations of $\mathrm{NO}_{2}^{-}$were the highest above $150 \mathrm{~m}$, and below this depth $\mathrm{NO}_{2}^{-}$decreased rapidly to reach values close to the detection limit at $200 \mathrm{~m}$. Above $150 \mathrm{~m}, \mathrm{NO}_{2}^{-}$ concentrations were clearly higher at the stations in the polar front zone (PFZ) $\left(\mathrm{NO}_{2}^{-}\right.$in the range $\left.0.3-0.4 \mu \mathrm{M}\right)$ than at those in the Antarctic zone (AZ) $\left(\mathrm{NO}_{2}^{-}\right.$of $\left.0.25 \mu \mathrm{M}\right)$.

Along the transect $\mathrm{E}-\mathrm{W}$, the highest $\mathrm{NO}_{2}^{-}$concentrations were measured at TEW-1 $(0.31-0.34 \mu \mathrm{M})$. Contrasting with the $\mathrm{NO}_{2}^{-}$distribution observed along the transect $\mathrm{N}-\mathrm{S}$, the stations of the AZ (i.e., west of the isocline $\sigma=27$ ) had higher concentrations than those of the PFZ. $\mathrm{NH}_{4}^{+}$concentrations were highest at the coastal stations. At stations TEW-1, concentrations of $\mathrm{NH}_{4}^{+}$increased from $0.19 \mu \mathrm{M}$ (at $10 \mathrm{~m}$ ) to $1.45 \mu \mathrm{M}$ (close to the bottom). The same trend was observed at TEW-2 $(0.17 \mu \mathrm{M}$ at $10 \mathrm{~m}$ and $0.39 \mu \mathrm{M}$ close to the bottom). At all stations offshore and above the plateau, a subsurface maximum of $\mathrm{NH}_{4}^{+}$peaking at $0.5-0.6 \mu \mathrm{M}$ was observed between 50 and $150 \mathrm{~m}$. The DON distribution was characterized by a northsouth gradient in the $0-150 \mathrm{~m}$ layer. DON concentrations above the Kerguelen plateau at stations A3-1 and TNS-10 $(6.0 \pm 1.0 \mu \mathrm{M})$ were similar to those in the meander of the PF $6.4 \pm 1.7 \mu \mathrm{M}$ (stations TNS-3 to TNS-7). But higher values were detected north of the PF $(8.6 \pm 1.2 \mu \mathrm{M}$ for stations TNS-1 and TNS-2). 

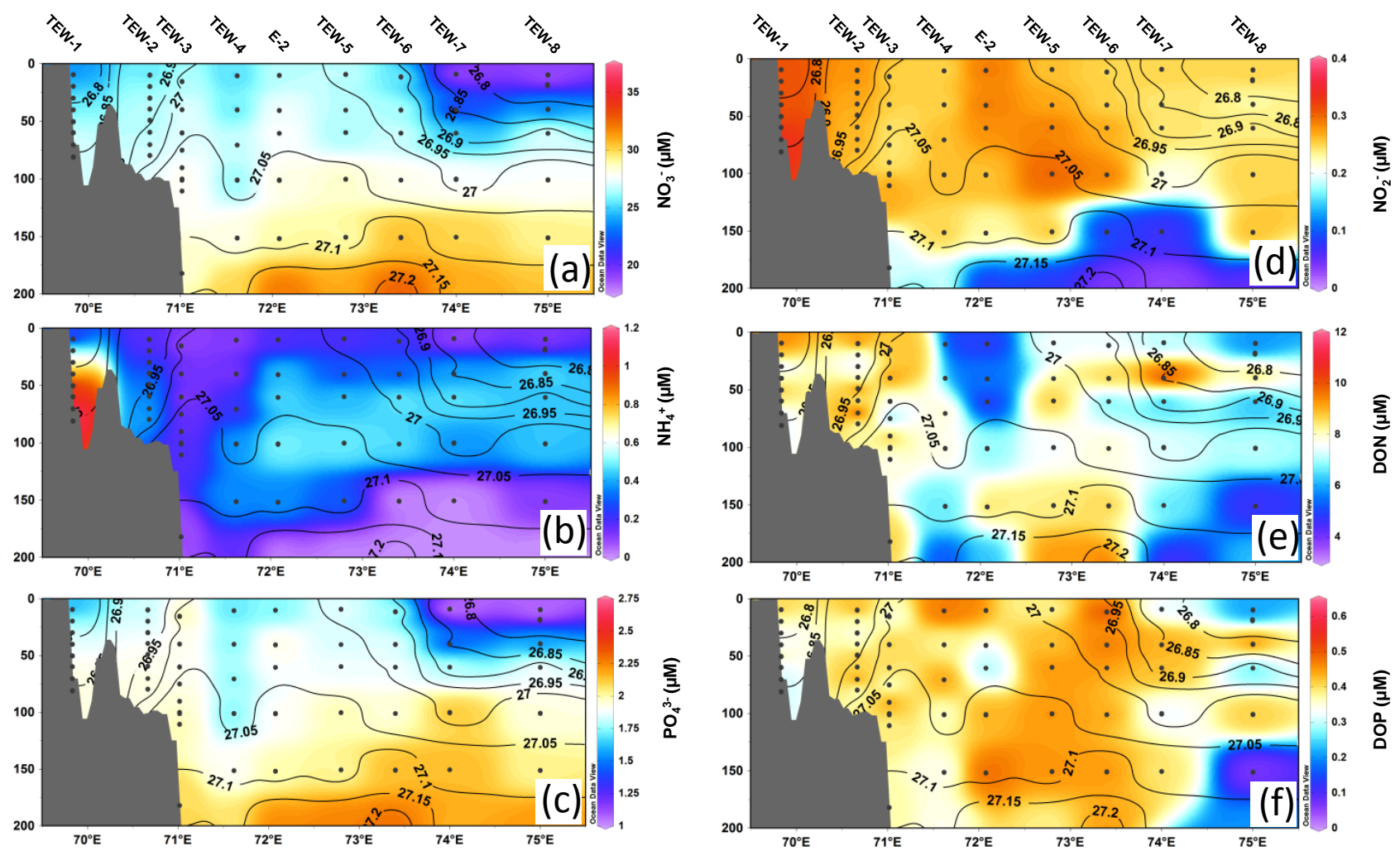

Figure 2. Vertical sections of dissolved nitrogen and phosphorus species along the East-West transect (TEW). (a) nitrate, (b) ammonium, (c) phosphate, (d) nitrite, (e) dissolved organic nitrogen, (f) dissolved organic phosphorus. The isolines for density anomaly $(\sigma)$ are plotted on each panel.

For DOP, the latitudinal gradient was less pronounced, but DOP concentrations were lower above the Kerguelen plateau than at any other sites.

\subsection{Speciation of dissolved nitrogen at selected sites}

\subsubsection{The Kerguelen plateau station A3}

The vertical distribution of different chemical nitrogen species during the two visits at station $\mathrm{A} 3$ are detailed in Fig. 4. $\mathrm{NO}_{3}^{-}$distributions are discussed in more detail in Sect. 3.3. Concentrations of $\mathrm{NO}_{2}^{-}$were, during both visits, homogeneous in the mixed layer and revealed a small maximum below the mixed layer depth (MLD). $\mathrm{NO}_{2}^{-}$increased from $0.27 \mu \mathrm{M}$ at A3-1 to $0.33 \mu \mathrm{M}$ at A3-2 (Fig. 4b). $\mathrm{NH}_{4}^{+}$concentrations roughly doubled between the two visits $(0.1 \mu \mathrm{M}$ at $\mathrm{A} 3-1$ to $0.2 \mu \mathrm{M}$ at $\mathrm{A} 3-2)$ and clear maxima were detectable at the base of the mixed layer. Concentrations of DON did not change between visits; however, DON accounted for $20 \%$ of TDN in the mixed layer at A3-1, and this contribution increased to $25 \%$ in the upper $40 \mathrm{~m}$ water layer at A3-2 (data not shown). Both $\mathrm{NO}_{3}^{-}$consumption and DON release during the 4 weeks that separated the two visits explained the increase in the percent DON of TDN. Below $200 \mathrm{~m}$, TDN was higher at A3-1 than at A3-2. This was mainly driven by the differences in DON concentrations that were higher at A3-1 $(4.7-6.7 \mu \mathrm{M})$ than at $\mathrm{A} 3-2(1.8-4 \mu \mathrm{M})$ in the 250-300 m layer (Fig. 4).

\subsubsection{Stations F-S and F-L north of the polar front}

Distinct vertical profiles of $\mathrm{NO}_{2}^{-}$and $\mathrm{NH}_{4}^{+}$were observed at station F-S. Concentrations of $\mathrm{NO}_{2}^{-}$decreased from $0.39 \mu \mathrm{M}$ at $10 \mathrm{~m}$ to $0.22 \mu \mathrm{M}$ at $93 \mathrm{~m}$. However, we note a remarkably low value of $0.15 \mu \mathrm{M}$ at $79 \mathrm{~m}$ (Fig. 5a). The $\mathrm{NH}_{4}^{+}$profile presented the same anomaly, resulting in two subsurface maxima. This feature contrasts with most other stations where a single subsurface maximum was observed, as for example at station F-L (Fig. 5b) located a few nautical miles away from F-S. We suggest that this anomaly is due to the position of F-S within the polar front where a complex mixing event at a small scale could have occurred. The contribution of DON to TDN at F-S decreased continuously from $34 \%$ at $20 \mathrm{~m}$ to $9 \%$ at $120 \mathrm{~m}$. However, close to the surface, the contribution of DON was only $17 \%$ (Fig. 5d).

\subsubsection{The HNLC station R-2}

The vertical distribution of $\mathrm{NO}_{3}^{-}$and $\mathrm{DON}$ revealed small variations between the surface and $200 \mathrm{~m}$ (Fig. 6a). DON 

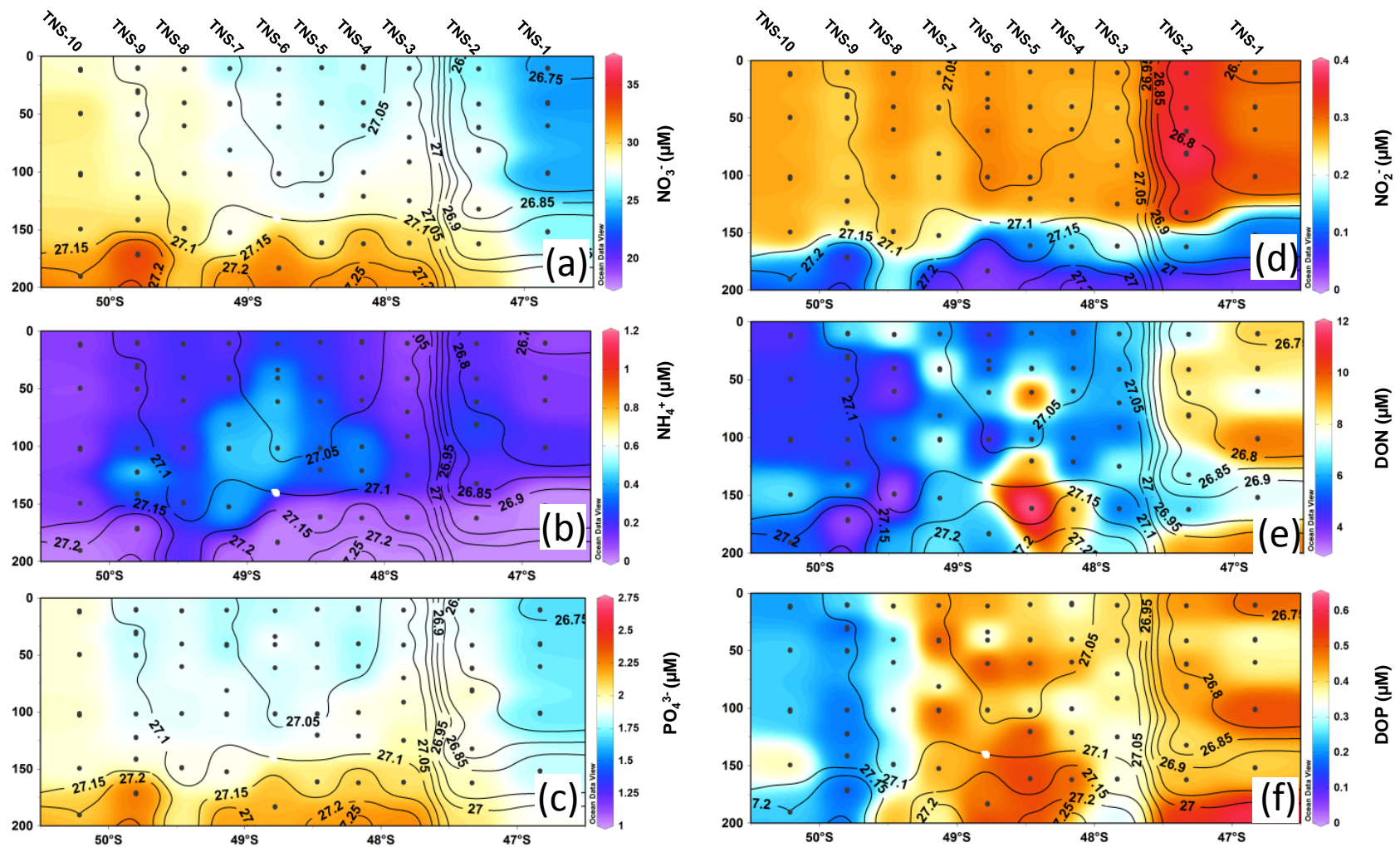

Figure 3. Vertical sections of dissolved nitrogen and phosphorus species along the North-South transect (TNS). (a) nitrate, (b) ammonium, (c) phosphate, (d) nitrite, (e) dissolved organic nitrogen, (f) dissolved organic phosphorus. The isolines for density anomaly $(\sigma)$ are plotted on each panel.

accounted for 19 to $24 \%$ of TDN, representing intermediate values as compared to the range observed in the fertilized region. Concentrations of $\mathrm{NO}_{2}^{-}$and $\mathrm{NH}_{4}^{+}$presented similar vertical distributions, decreasing rapidly below the mixed layer (Fig. 6b). Concentrations of $\mathrm{NH}_{4}^{+}$in the mixed layer $(0.07 \mu \mathrm{M})$ were at least two-fold lower than at any other stations, and $\mathrm{NO}_{2}^{-}$concentrations in the mixed layer $(0.3 \mu \mathrm{M})$ were similar to those of the mixed layers in the fertilized regions.

\subsubsection{The Lagrangian sites $\mathbf{E}$}

All stations were characterized by similar vertical distributions of $\mathrm{NO}_{2}^{-}$and $\mathrm{NH}_{4}^{+}$. Concentrations in the mixed layer were in the range $0.25-0.3 \mu \mathrm{M}$ decreasing to $0.02-0.03 \mu \mathrm{M}$ below $200 \mathrm{~m}$. The vertical distributions of $\mathrm{NH}_{4}^{+}$are characterized by a subsurface maximum with concentrations (0.4$0.65 \mu \mathrm{M})$ two-fold higher than at the surface $(0.2-0.3 \mu \mathrm{M})$. $\mathrm{NO}_{3}^{-}$distributions are described in more detail in the next section. The contribution of DON to TDN in the mixed layer was in the range of $15-25 \%$. No clear temporal evolution was detectable.

\subsection{Temporal evolution of the vertical distributions of nitrate and phosphate}

\subsubsection{The Lagrangian sites $E$}

The vertical profiles of $\mathrm{NO}_{3}^{-}$and $\mathrm{PO}_{4}^{3-}$ concentrations in the upper $200 \mathrm{~m}$ of five stations located in the center of a meander of the PF are presented in Fig. 7. In addition, we show data from two other cruises. Samples collected in early October 1995 during the cruise ANTARES3 (Blain et al. 2001) provided data typical of winter conditions. Samples of the KEOPSMOOR profile were collected in February 2013, representing post-bloom conditions.

Concentrations of $\mathrm{NO}_{3}^{-}$were almost identical among visits at $150 \mathrm{~m}$ (mean $27.5 \pm 0.8 \mu \mathrm{mol} \mathrm{L}^{-1}$, Fig. 7a). Above $150 \mathrm{~m}, \mathrm{NO}_{3}^{-}$concentrations change along the season. In winter, concentrations were homogenous from the surface to $150 \mathrm{~m}$, resulting in a mean integrated stock of $4.22 \pm 0.08 \mathrm{~mol} \mathrm{~m}^{-2}$. In spring, the KEOPS 2 profiles qualitatively clustered into two groups. The first cluster is composed of stations TNS-5, TNS-6, E-1, E-2 and E-3 with higher $\mathrm{NO}_{3}^{-}$concentrations (mean integrated stock 0 $150 \mathrm{~m}$ of $4.10 \pm 0.05 \mathrm{~mol} \mathrm{~m}^{-2}$ ) than in the group formed by stations E4-E and E-5 (mean integrated stock 0-150 m of $3.90 \pm 0.04 \mathrm{~mol} \mathrm{~m}^{-2}$ ). Finally, the lowest concentrations 


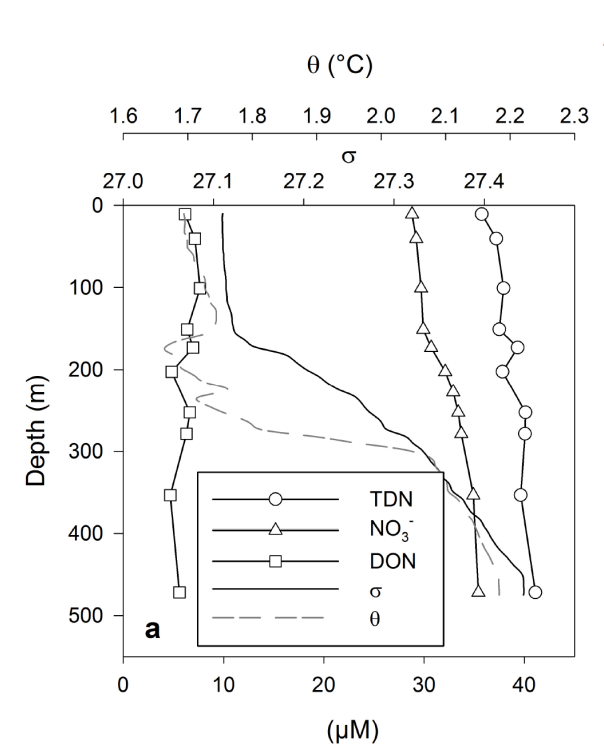

A3-1
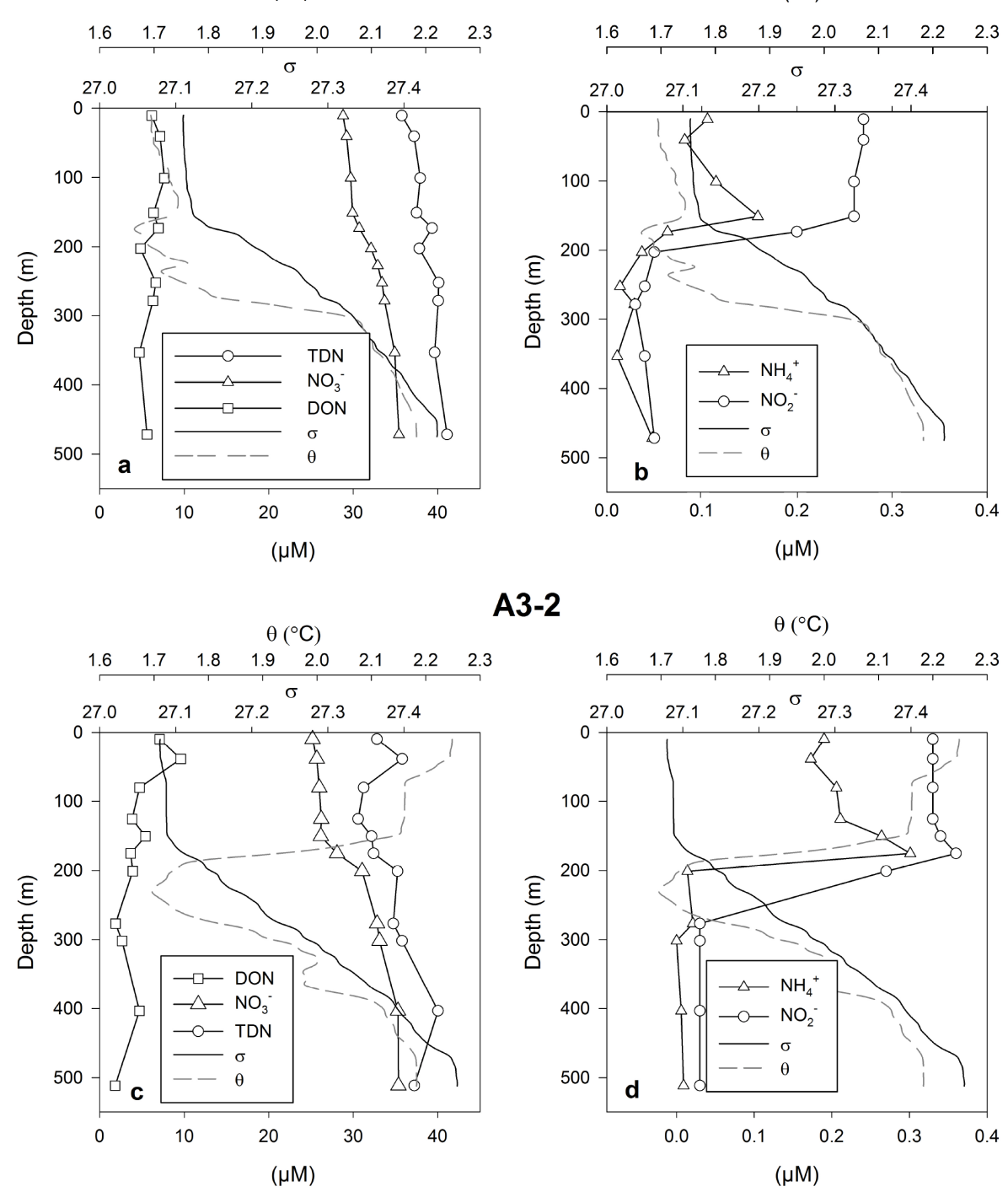

A3-2

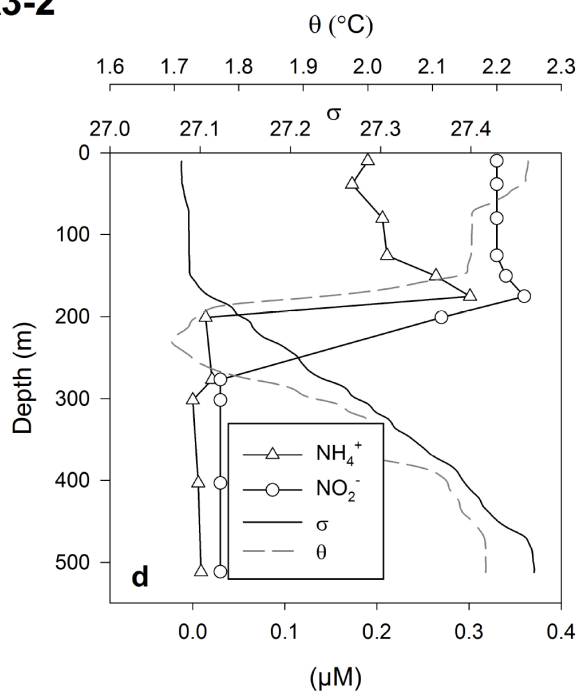

Figure 4. Dissolved nitrogen speciation at station A3-1 (a, b) and at station A3-2 (c, d) during KEOPS2. Depth profiles of temperature and $\sigma-\theta$ are plotted on each panel.

were measured in summer (mean integrated stock $0-150 \mathrm{~m}$ of $3.48 \mathrm{~mol} \mathrm{~m}^{-2}$ ).

Vertical profiles of $\mathrm{PO}_{4}^{3-}$ presented similar characteristics as $\mathrm{NO}_{3}^{-}$, with the exception of the winter profile (Fig. $7 \mathrm{~b}$ ). The winter profile indicates that $\mathrm{PO}_{4}^{3-}$ concentrations are homogenously mixed in the upper $150 \mathrm{~m}$. The concentrations seem overestimated at $150 \mathrm{~m}$ and above. We do not think that the differences result from interannual variability because this would have also impacted $\mathrm{NO}_{3}^{-}$concentrations. The high concentrations of $\mathrm{PO}_{4}^{3-}$ measured in winter 1995 lead to a $\mathrm{NO}_{3}^{-}: \mathrm{PO}_{4}^{3-}$ ratio of 12.5 which is low. The overestimation of $\mathrm{PO}_{4}^{3-}$ could result from methodological issues. The ANTARES3 samples were not analyzed aboard, but a few months later in a laboratory by a different analytical protocol. The lack of certified international standards necessary for strong quality control of the accuracy precludes rigorous comparison of samples collected in 1995 with more recent samples.

Similarly to $\mathrm{NO}_{3}^{-}$, we consider the mean concentration of $\mathrm{PO}_{4}^{3-}$ at $150 \mathrm{~m}$ (excluding the ANTARES3 $\mathrm{PO}_{4}^{3-}$ value) to estimate a mean winter $\mathrm{PO}_{4}^{3-}$ concentration in the surface layer of $1.93 \pm 0.09 \mu \mathrm{mol} \mathrm{L}^{-1}$ that yields an integrated winter stock of $0.30 \pm 0.02 \mathrm{~mol} \mathrm{~m}^{-2}$. The integrated stock for the group of stations E-1-E-3 $\left(0.280 \pm 0.004 \mathrm{~mol} \mathrm{~m}^{-2}\right)$ was higher than for the group E-4-E-5 $\left(0.274 \pm 0.005 \mathrm{~mol} \mathrm{~m}^{-2}\right)$. At the end of the season the integrated $\mathrm{PO}_{4}^{3-}$ stock was $0.250 \mathrm{~mol} \mathrm{~m}^{-2}$. 

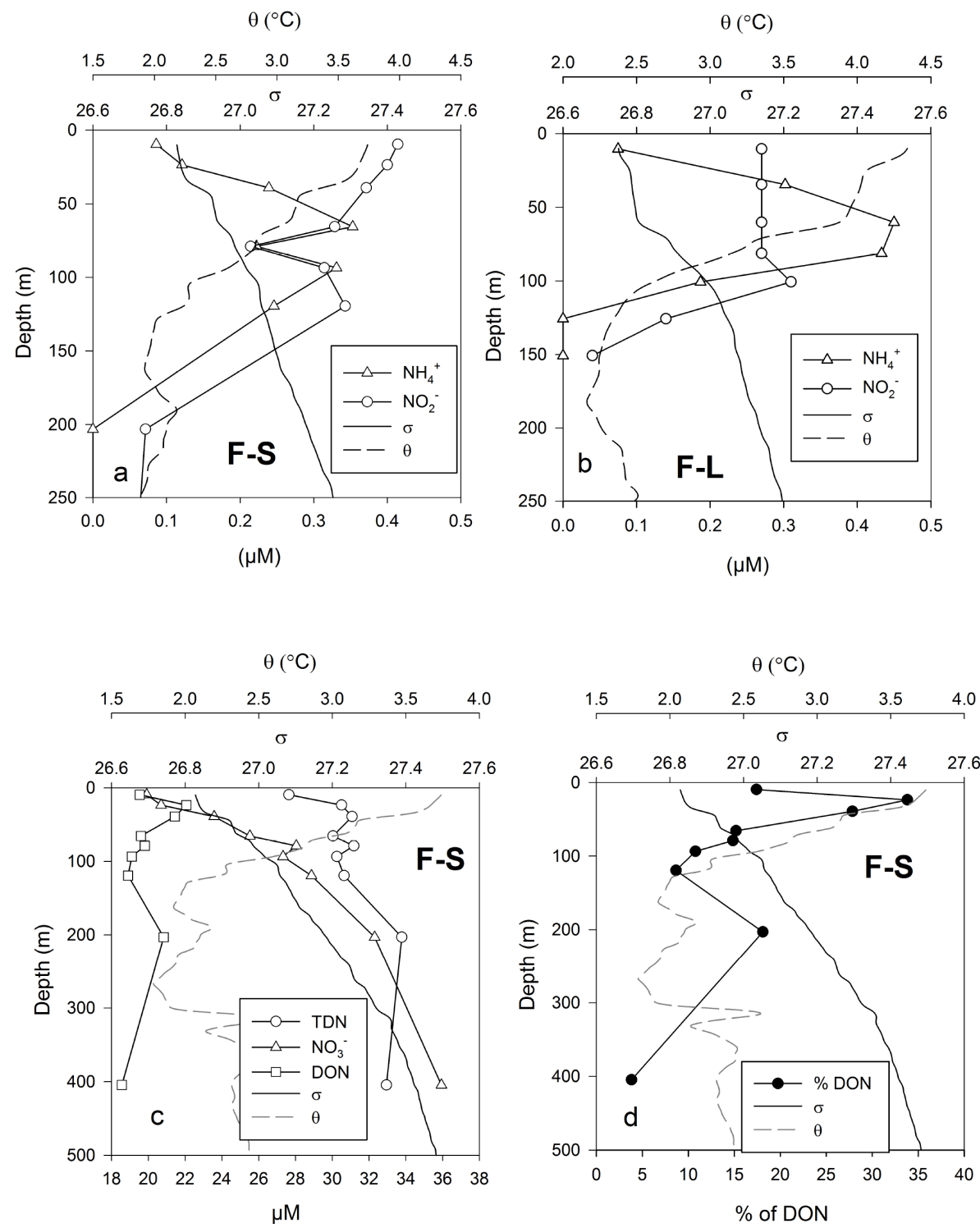

Figure 5. Dissolved nitrogen speciation at stations F-L and F-S during KEOPS2.

\subsubsection{The Kerguelen plateau station A3}

At station $\mathrm{A} 3$, vertical profiles of changes of $\mathrm{NO}_{3}^{-}$and $\mathrm{PO}_{4}^{3-}$ concentrations were observed between spring and summer (Fig. 8). Although the stations were sampled in November 2011 and February 2013, we consider these variations as seasonal changes. The profiles of both nutrients merge at $200 \mathrm{~m}$ in early spring and summer (A3-1 and A3-2). However, during the second visit at A3 (A3-2), we observed that the surface layer was mixed down to $170 \mathrm{~m}$. We propose that the concentrations at $200 \mathrm{~m}$ are a good estimate of the winter concentrations of $\mathrm{NO}_{3}^{-}$and $\mathrm{PO}_{4}^{3-}$ at this station. Thus, winter stocks $(0-200 \mathrm{~m})$ were 6.27 and $0.43 \mathrm{~mol} \mathrm{~m}^{-2}$ for $\mathrm{NO}_{3}^{-}$ and $\mathrm{PO}_{4}^{3-}$, respectively. At the first visit at station $\mathrm{A} 3$ the stocks had decreased to 5.96 and $0.41 \mathrm{~mol} \mathrm{~m}^{-2}$. Four weeks later (A3-2) they reached 5.29 and $0.36 \mathrm{~mol} \mathrm{~m}^{-2}$. Finally, in February the stocks were 4.77 and $0.35 \mathrm{~mol} \mathrm{~m}^{-2}$.

\section{Discussion}

The distributions of $\mathrm{NO}_{3}^{-}$and $\mathrm{PO}_{4}^{3-}$ in the world's oceans have been extensively studied over the past decades. A major rationale for this research is the critical role of these major nutrients for phytoplankton growth and therefore marine primary production. Further, concentrations of $\mathrm{NO}_{3}^{-}$and $\mathrm{PO}_{4}^{3-}$ are used as tracers for biogeochemical processes in the ocean (Deutsch and Weber, 2012). In the Southern Ocean, south of the sub-Antarctic front, $\mathrm{NO}_{3}^{-}$and $\mathrm{PO}_{4}^{3-}$ concentrations are high. They are therefore considered as non-limiting and much less attention has been paid to their distributions as 


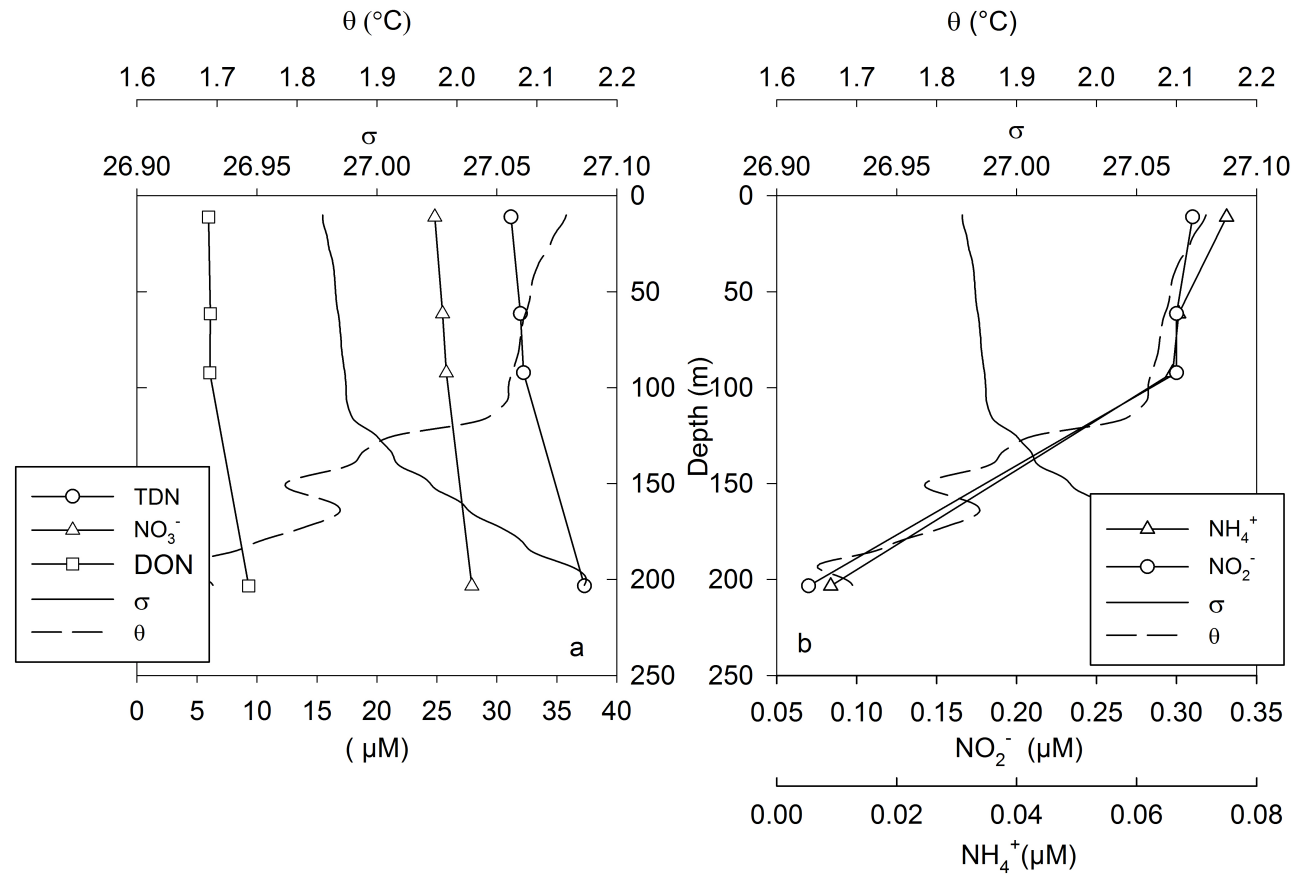

Figure 6. Dissolved nitrogen speciation at station R-2.
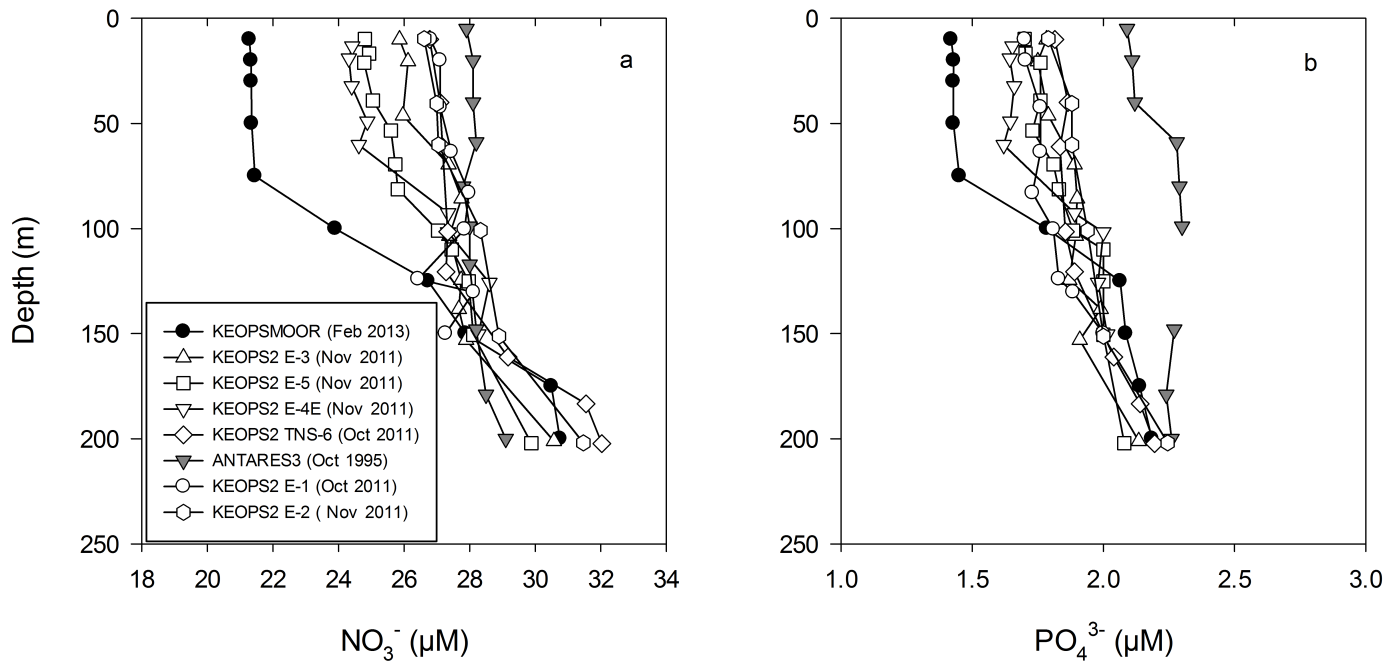

Figure 7. Temporal variability of the vertical profiles of concentrations of $\mathrm{NO}_{3}^{-}$(a) and $\mathrm{PO}_{4}^{3-}$ (b) for stations located in the meander of the polar front. Details for profiles of KEOPSMOOR (February 2013) and ANTARES3 (October 1995) are provided in the text.

compared to other nutrients such as silicic acid or dissolved iron. However, the relaxation of iron limitation by natural or artificial fertilizations offers a different perspective because $\mathrm{NO}_{3}^{-}$and $\mathrm{PO}_{4}^{3-}$ should be consumed as the bloom develops. This has motivated the present detailed study of dissolved $\mathrm{N}$ and $\mathrm{P}$ in the naturally fertilized region of Kerguelen.

To explore the dynamics of $\mathrm{NO}_{3}^{-}$and $\mathrm{PO}_{4}^{3-}$ we examined their stoichiometry in the study region. This is commonly done by establishing the ratio $r_{\mathrm{N}: \mathrm{P}}=\left[\mathrm{NO}_{3}^{-}\right]:\left[\mathrm{PO}_{4}^{3-}\right]$ for comparison with the Redfield ratio of 16 (Redfield et al., 1963). However, the significance of $r_{\mathrm{N}}$ : $\mathrm{P}$ is limited because this ratio is not conserved by mixing or biological processes such as uptake or remineralization (Deutsch and Weber, 2012). We therefore calculated the linear combination $N^{*}=\left[\mathrm{NO}_{3}^{-}\right]-16\left[\mathrm{PO}_{4}^{3-}\right]$, similar to the parameter first introduced by Michaels et al., 1996, but omitting the constant term required to obtain a global average of $N^{*}$ equal to $0 . N^{*}$ traces the impact of processes that add or remove $\mathrm{N}$ and $\mathrm{P}$ with a stoichiometry different from the Redfield ratio of 16. At almost all stations and depths, $N^{*}$ was close 

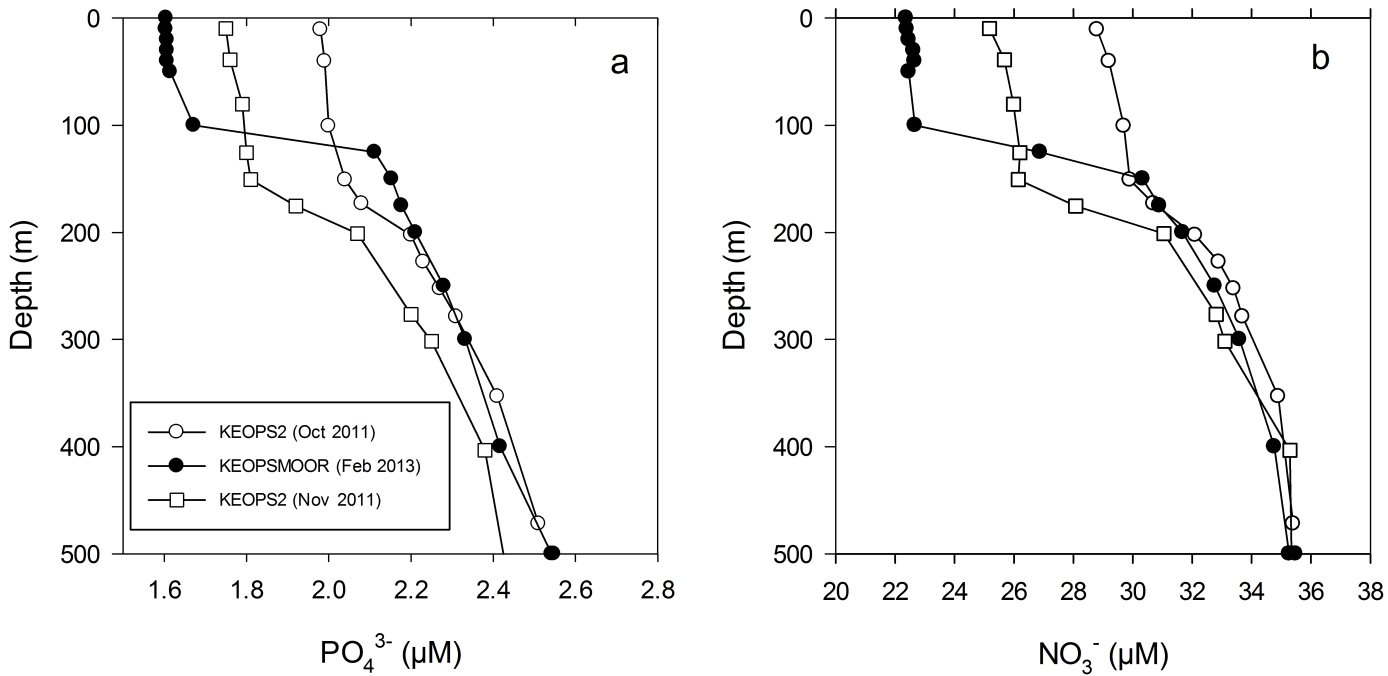

Figure 8. Temporal variability of the vertical profiles of concentrations of $\mathrm{NO}_{3}^{-}$(a) and $\mathrm{PO}_{4}^{3-}(\mathbf{b})$ at the station $\mathrm{A} 3$.
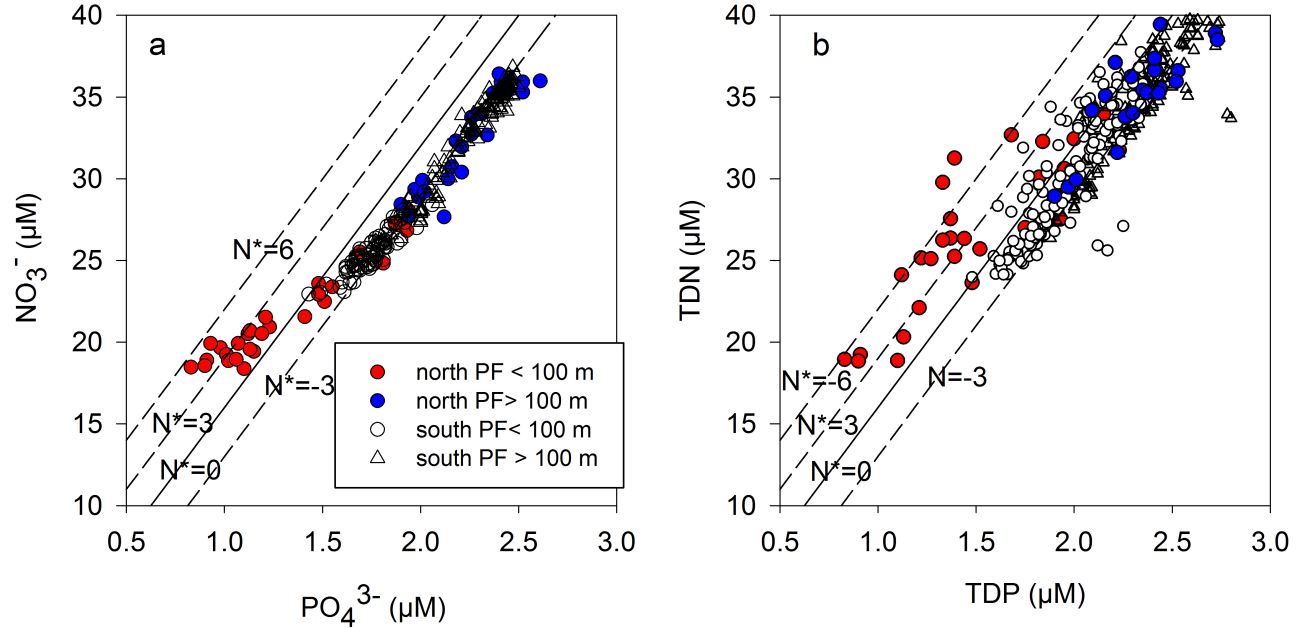

Figure 9. (a) Comparison of concentrations of $\mathrm{NO}_{3}^{-}$versus $\mathrm{PO}_{4}^{3-}$. Dots denote the samples, and lines show different values of $N^{*}=\mathrm{NO}_{3}^{-}-r_{\mathrm{N}}: \mathrm{PO}_{4}^{3-}$. (b) Comparison of concentrations of TDN versus TDP, dots denote the samples and lines show different values of $\mathrm{TN}_{\mathrm{XS}}=\mathrm{TDN}-r_{\mathrm{N}}: \mathrm{P}$ TDP.

to $-3 \mu \mathrm{M}$ (Fig. 9a). This value agrees well with the mean $N^{*}$ computed for regions of the Southern Ocean close to the PF (Weber and Deutsch, 2010). A noticeable deviation from this value was observed for a set of data where $N^{*}$ increased from $N^{*}=-3 \mu \mathrm{M}$ to $N^{*}=6 \mu \mathrm{M}$. All data with $N^{*}>0$ are for samples collected in the mixed layer north of the PF, and located in a bloom where diatoms contributed $70 \%$ of the carbon biomass in the euphotic layer (Lasbleiz et al., 2014).

Nutrient drawdown lower than the Redfield ratio has been observed previously in the Southern Ocean. During the artificial iron fertilization experiment EIFEX, an apparent differential consumption of $\Delta\left(\mathrm{NO}_{3}^{-}\right): \Delta\left(\mathrm{PO}_{4}^{3-}\right)$ of 6.4 was reported (Smetacek et al., 2012). Arrigo (1999) and De Baar et al. (1997) determined a nutrient drawdown ratio in diatom blooms of 9.7 and 4.4-6.1, respectively. Near the Crozet Islands, the removal of $\mathrm{NO}_{3}^{-}$versus $\mathrm{PO}_{4}^{3-}$ measured in situ and during iron-addition experiments revealed that the ratio was inversely related to the proportion of diatoms in the phytoplankton community (Moore et al., 2007). All these studies confirm the impact of diatom blooms on nutrient stoichiometry in the surface layer. However, the interpretations of these observations are diverse. De Baar et al. (1997) suggested that the preferential drawdown of $\mathrm{PO}_{4}^{3-}$ during the bloom of Fragilariopsis kerguelensis in the PF could be due to the dominance of Fragilariopsis kerguelensis because of the physiological trait of low $\mathrm{N}: \mathrm{P}$ ratio. These hypotheses could not explain our observations because the stations with a nutrient drawdown anomaly were located in an iron-fertilized 

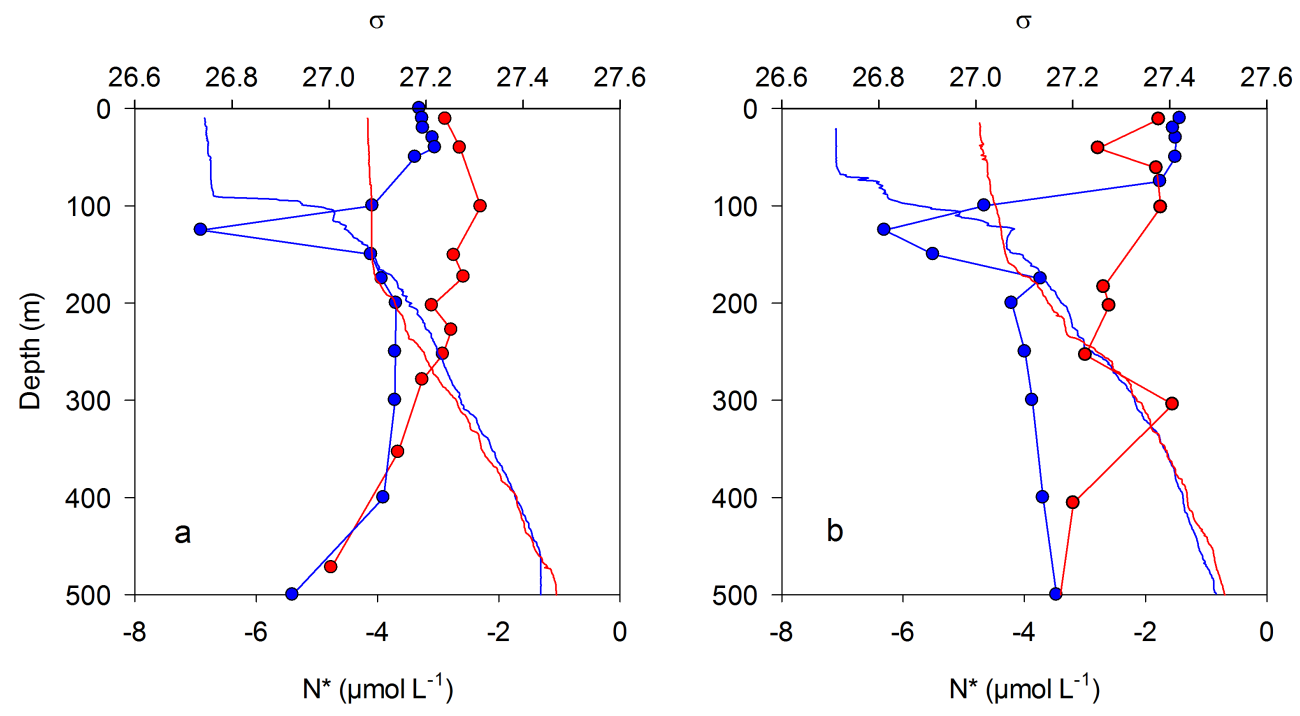

Figure 10. Depth profiles of $N^{*}$ at stations A3 (a) and TNS-6 (b) for the month of November (in red) and February (in blue). Vertical profiles of density anomaly are shown with the same color.

region and the diatom community was not dominated by Fragilariopsis kerguelensis but rather by Chaetoceros (Hylochaete) spp., Pseudo-nitzschia spp. and Centric sp. (Lasbleiz et al., 2014).

Thus, we interpret the positive values of $N^{*}$ as a result of the preferential uptake of $\mathrm{PO}_{4}^{3-}$ versus $\mathrm{NO}_{3}^{-}$by fast-growing diatoms. Diatoms have a mean elemental N:P stoichiometry of $10 \pm 4$ (Sarthou et al., 2005), which differs from the Redfield value. Indeed, the elemental particulate matter composition determined at the stations with positive $N^{*}$ during KEOPS2 (Lasbleiz et al., 2014) exhibits a mean ratio of particulate organic nitrogen to particulate organic phosphorus (PON : POP) of $10.5 \pm 3.3$ which is consistent with the observed nutrient drawdown $\Delta\left(\mathrm{NO}_{3}^{-}\right): \Delta\left(\mathrm{PO}_{4}^{3-}\right)$ of 8 . We suggest that the preferential allocation of resources to the P-rich assembly of the cell machinery by exponentially growing cells is the most likely explanation for our observations (Klausmeier et al., 2004). The anomaly observed for the present data set is not linked to a particular species but to general traits of the diatom community responding to iron fertilization.

As a variant of $N^{*}$, the tracer $\operatorname{DIN}_{\mathrm{xs}}$, takes into account $\mathrm{NO}_{2}^{-}$and $\mathrm{NH}_{4}^{+}$(Hansell et al., 2007), but none of those tracers consider the organic pools of $\mathrm{N}$ and P. Landolfi et al. (2008) have defined the tracer $\mathrm{TN}_{\mathrm{xs}}=$ [TDN]-16[TDP] and have shown that the dissolved organic fraction significantly contributes to changes in $\mathrm{TN}_{\mathrm{xs}}$. For example, relying on $N^{*}$ only, can lead to an underestimation of $\mathrm{N}_{2}$ fixation at the global scale (Landolfi et al., 2008). In the case of KEOPS2, the contribution of DON and DOP to TDN and TDP reached $30 \%$. We have therefore considered TDN and TDP at all KEOPS2 stations where these measurements were available (Fig. 9b). Plotting TDN as a function of TDP
$(\mathrm{TDN}=f(\mathrm{TDP}))$ reveals more dispersion of the data than $\mathrm{NO}_{3}^{-}=f\left(\mathrm{PO}_{4}^{3-}\right)$, mainly due to the lower analytical precision for DOP and DON determinations. Still, clear trends are detectable. $\mathrm{TN}_{\mathrm{xs}}$ values were negative for most stations and depths, and relatively constant in the $0-500 \mathrm{~m}$ layer. As for $N^{*}$ the stations north of the PF had higher $\mathrm{TN}_{\mathrm{xs}}$ in the 0 $100 \mathrm{~m}$ layer.

When a water parcel is considered, $N^{*}$ is affected by the redistribution of $\mathrm{N}$ and $\mathrm{P}$ between the inorganic and the organic pools, whereas $\mathrm{TN}_{\mathrm{xs}}$ is only affected by net nonRedfield sources or sinks of N and P. Consequently, the positive anomaly observed for $\mathrm{TN}_{\mathrm{xs}}$ in surface waters north of the $\mathrm{PF}$ can be explained by three possible mechanisms: deposition of $\mathrm{N}$-rich material from the atmosphere, $\mathrm{N}_{2}$ fixation and export of P-rich material. The region of Kerguelen receives low quantities of atmospheric material (Heimburger et al., 2012; Wagener et al., 2008) which is mainly of natural origin, such as desert dust, which contains little nitrogen compared to phosphorus (Zamora et al., 2013). This is confirmed by the low $\mathrm{N}$ deposition rate estimated around the Crozet Islands $\left(2 \mathrm{nmol} \mathrm{m}^{-2} \mathrm{~d}^{-1}\right.$; Planquette et al., 2007). We can therefore refute the deposition of $\mathrm{N}$-rich material as the cause of the $\mathrm{TN}_{\mathrm{xs}}$ anomaly. The second hypothesis involves $\mathrm{N}_{2}$ fixation. To date, $\mathrm{N}_{2}$ fixation has not been reported to occur in the cold waters of the Southern Ocean. However, during KEOPS2 detectable $\mathrm{N}_{2}$ fixation rates were measured at different stations with a few exceptionally high values $\left(\sim 250 \mu \mathrm{mol} \mathrm{m}^{-2} \mathrm{~d}^{-1}\right)$ in the mixed layer of station F-L (Gonzàlez et al., 2015). Such high fixation rates could contribute to an enrichment of about $1 \%$ of TDN that is not enough to create the observed anomaly. If $\mathrm{N}_{2}$ fixation was a dominant process driving the $\mathrm{N}: \mathrm{P}$ stoichiometry at this station, particulate organic matter (POM) elemental composition should also be affected. 
Generally, $\mathrm{N}_{2}$ fixing microorganisms have a high $\mathrm{N}$ : $\mathrm{P}$ ratio (Laroche and Breitbarth, 2005). Such high ratios are at odds with the low $\mathrm{N}$ : $\mathrm{P}$ measured in the POM at station F-L (Lasbleiz et al., 2014). The third hypothesis for explaining the anomaly relies on the export of P-rich material from the mixed layer. We do not have direct measurements of $\mathrm{N}: \mathrm{P}$ in the exported material, but we have already mentioned above that the elemental composition of particulate matter at station F-L yielded the lowest $\mathrm{N}: \mathrm{P}$ ratio in POM (Lasbleiz et al., 2014). This provides support for the export of P-rich material resulting in high $\mathrm{TN}_{\mathrm{xs}}$ values north of the PF. We propose that the anomaly of $\mathrm{TN}_{\mathrm{xs}}$ results from the imprint on stoichiometry of the diatom bloom which consumed and exported phosphorus with a N:P ratio below the Redfield value.

During KEOPS2, rapidly growing diatom blooms were also sampled at other stations located south of the PF, but anomalies similar to those at F-L were not observed. We discuss here the case of stations A3 and E- $4 \mathrm{~W}$, which had similar chlorophyll concentrations as F-L. Station A3 had a contribution of diatoms to carbon biomass and dominant diatom species similar to F-L (these observations are not available for E4-W) (Lasbleiz et al., 2014). There is no reason that the physiological features of exponentially growing diatoms as revealed for station F-L do not apply to the diatoms growing at stations $\mathrm{A} 3$ and $\mathrm{E} 4-\mathrm{W}$. It is, however, possible that the resulting effect is not large enough to translate into $N^{*}$ or $\mathrm{TN}_{\mathrm{xs}}$ anomalies. A possible explanation could be the differences in the age of the blooms. The stoichiometry would be less affected in a younger bloom as compared to a bloom of longer duration. This hypothesis cannot be fully verified due to the poor temporal resolution of the satellite ocean color images available (see supplementary animations provided in Trull et al., 2014). Another or complementary explanation is the difference in the mixed layer depths that were 50 and $150 \mathrm{~m}$ at stations F-L and A3-2, respectively. Such a deep mixed layer as observed at station A3-2 likely resulted from a deep episodic mixing event generated by strong winds prevailing during the day preceding our visit. The deepening could have dampened the anomaly by diluting and mixing the affected water parcel with underlying water having a typical stoichiometry (e.g., $N^{*}$ or $\mathrm{TN}_{\mathrm{xs}}$ around -3 ).

In February 2013, 2 years after the KEOPS2 cruise, we were able to return to two sites visited during KEOPS2 (stations A3 and TNS-6) and obtain measurements for the concentrations of $\mathrm{NO}_{3}^{-}$and $\mathrm{PO}_{4}^{3-}$. These data, in combination with KEOPS2 data, allowed us to compare $N^{*}$ during two different seasons (Fig. 10). In the mixed layer, little change in $N^{*}$ was observed between spring and summer. However, in summer, $N^{*}$ exhibited a clear subsurface minimum between $100-200 \mathrm{~m}$ at both stations. Denitrification is a process that could produce this subsurface feature. But denitrification would require low oxygen concentrations that are not observed at these stations. In a general manner, preferential remineralization of $\mathrm{P}$ versus $\mathrm{N}$ in the water column is supported by an increase of $\mathrm{N}: \mathrm{P}$ in high molecular dissolved or- ganic matter (Clark, et al., 1998) in particulate matter (CopinMontegut and Copin-Montegut, 1978) and in supernatant of sediment trap material (Lourey et al., 2003). The observation of the $N^{*}$ subsurface minimum at the end of the season, but not at the beginning implies a temporal cumulative effect. The minimum is located just below the mixed layer in the region of the pycnocline that presents the highest density gradient. This could represent a zone with a higher residence time for sinking particles resulting in an accumulation of biomass. Additional evidence for intensive remineralization at shallow depths at this location is provided by the strong attenuation of the particles fluxes as observed with moored sediment trap (Rembauville et al., 2015). Consequently, the remineralization would also be increased in this layer compared to the rest of the water column resulting in a higher accumulation of $\mathrm{PO}_{4}^{3-}$ relative to $\mathrm{NO}_{3}^{-}$. This effect might be amplified by the occurrence of particulate organic matter with a low $\mathrm{N}: \mathrm{P}$ ratio resulting from diatom accumulation at the pycnocline. As the subsurface minimum is located above $200 \mathrm{~m}$ depth, it is erased when winter mixing occurs.

To our knowledge, such a subsurface minimum has not be reported in the Southern Ocean. This could be due to the limited studies that investigate concurrently dissolved $\mathrm{N}$ and $\mathrm{P}$ biogeochemistry, and to the lack of samples collected at the appropriate vertical and temporal time scale. Our finding raises several further questions. Is the subsurface minimum of $N^{*}$ a particular feature of iron-fertilized regions? What is the link between its occurrence and the strength of stratification of the water column? And what is the role of this layer in the remineralization of carbon? These questions argue for future detailed investigation of the cycling of both elements in the upper layer of the Southern Ocean.

\section{The Supplement related to this article is available online at doi:10.5194/bg-12-623-2015-supplement.}

Acknowledgements. We thank the chief scientist Bernard Quéguiner, the captain Bernard Lassiette and the crew of the R/V Marion Dufresne for their support aboard. We thank C. Lo Monaco for providing us with the CTD profiles of KEOPSMOOR. This work was supported by the French research program of INSUCNRS LEFE-CYBER (Les enveloppes fluides et l'environnement - Cycles biogéochimiques, environnement et ressources), the French ANR (Agence Nationale de la Recherche, SIMI-6 program, ANR-10-BLAN-0614), the French CNES (Centre National d'Etudes Spatiales) and the French Polar Institute IPEV (Institut Polaire Paul-Emile Victor).

Edited by: T. Trull 


\section{References}

Aminot, A. and Kérouel, R.: Dosage automatique des nutriments dans les eaux marines, méthodes en flux continu, Ifremer, 2007.

Arrigo, K. R.: Phytoplankton Community Structure and the Drawdown of Nutrients and $\mathrm{CO}_{2}$ in the Southern Ocean, Science, 283, 365-367, 1999.

Blain, S., Quéguiner, B., Armand, L., Belviso, S., Bombled, B., Bopp, L., Bowie, A., Brunet, C., Brussaard, K., Carlotti, F., Christaki, U., Corbière, A., Durand, I., Ebersbach, F., Fuda, J. L., Garcia, N., Gerringa, L. J. A., Griffiths, F. B., Guigue, C., Guillerm, C., Jacquet, S., Jeandel, C., Laan, P., Lefèvre, D., Lomonaco, C., Malits, A., Mosseri, J., Obernosterer, I., Park, Y. H., Picheral, M., Pondaven, P., Remenyi, T., Sandroni, V., Sarthou, G., Savoye, N., Scouarnec, L., Souhault, M., Thuillers, D., Timmermans, K. R., Trull, T., Uitz, J., Van-Beek, P., Veldhuis, M. J. W., Vincent, D., Viollier, E., Vong, L., and Wagener, T.: Effect of natural iron fertilisation on carbon sequestration in the Southern Ocean, Nature, 446, 1070-1075, 2007.

Boyd, P. W., Jickells, T., Law, C., Blain, S., Boyle, E. A., Buesseler, K. O., Coale, K. H., Cullen, J. J., De Baar, H. J. W., Follows, M., Harvey, M., Lancelot, C., Levasseur, M., Owens, N. J. P., Pollard, D. A., Rivkin, R. B., Sarmiento, J. L., Schoemann, V., Smetacek, V., Takeda, S., Tsuda, A., Turner, D. R., and Watson, A.: Mesoscale iron enrichment experiments 1993-2005: Synthesis and future directions, Science, 315, 612-617, 2007.

Clark, L. L., Ingall, E., and Benner, R.: Marine phosphorus is selectively remineralized, Nature, 393, p. 426, 1998.

Copin-Montegut, C. and Copin-Montegut, G.: the chemistry of particulate matter from the south indien and antarctic ocean, DeepSea Res., 25, 911-931, 1978.

De Baar, H. J. W., Van Leeuwe, M. A., Scharek, R., Goeyens, L., Bakker, K. M. J., and Fritsche, P.: Nutrient anomalies in Fragilariopsis kerguelensis blooms, iron deficiency and the nitrate/phosphate ratio (A. C. Redfield) of the Antarctic Ocean, Deep-Sea Res. Pt. II, 44, 229-260, 1997.

Deutsch, C. and Weber, T.: Nutrient Ratios as a Tracer and Driver of Ocean Biogeochemistry, Annu. Rev. Mar. Sci., 4, 113-141, 2012.

Gnanadesikan, A., Sarmiento, J. L., and Slater, R. D.: Effects of patchy ocean fertilization on atmospheric carbon dioxide and biological production, Global Biogeochem. Cy., 17, 1050, doi:10.1029/2002GB001940, 2003.

González, M. L., Molina, V., Florez-Leiva, L., Oriol, L., Cavagna, A. J., Dehairs, F., Farias, L., and Fernandez, C.: Nitrogen fixation in the Southern Ocean: a case of study of the Fe-fertilized Kerguelen region (KEOPS II cruise), Biogeosciences Discuss., 11, 17151-17185, doi:10.5194/bgd-11-17151-2014, 2014.

Hansell, D. A., Olson, D. B., Dentener, F., and Zamora, L. M.: Assessment of excess nitrate development in the subtropical North Atlantic, Maine Chem., 206, 562-579, 2007.

Hart, T. J.: Phytoplankton periodicity in Antarctic surface water, Discov. Rep., VIII, 1-268, 1942.

Heimburger, A., Losno, R., Triquet, S., Dulac, F., and Mahowald, N.: Direct measurements of atmospheric iron, cobalt, and aluminum-derived dust deposition at Kerguelen Islands, Global Biogeochem. Cy., 26, GB4016, doi:10.1029/2012GB004301, 2012.
Holmes, R. M., Aminot, A., Keìrouel, R., Hooker, B., and peterson, B.: a simple and precise method for measuring ammonium in marine and freshwater ecosystem, 56, 1801-1808, 1999.

Jenkins, B. D., Gordon, L. I., and Nelson, D. M.: Nutrient depletion indicates high primary productivity in the Weddel Sea, Nature, 309, 51-54, 1984.

Klausmeier, C. A., Litchman, E., Daufresne, T., and Levin, S. A.: Optimal nitrogen-to-phosphorus stoichiometry of phytoplankton, Nature, 429, 171-174, 2004.

Landolfi, A., Oschlies, A., and Sanders, R.: Organic nutrients and excess nitrogen in the North Atlantic subtropical gyre, Biogeosciences, 5, 1199-1213, doi:10.5194/bg-5-1199-2008, 2008.

Laroche, J. and Breitbarth, E.: Importance of the diazotrophs as a source of new nitrogen in the ocean, J. Sea Res., 53, 67-91, 2005.

Lasbleiz, M., Leblanc, K., Blain, S., Ras, J., Cornet-Barthaux, V., Hélias Nunige, S., and Quéguiner, B.: Pigments, elemental composition $(\mathrm{C}, \mathrm{N}, \mathrm{P}$, and $\mathrm{Si})$, and stoichiometry of particulate matter in the naturally iron fertilized region of Kerguelen in the Southern Ocean, Biogeosciences, 11, 5931-5955, doi:10.5194/bg-115931-2014, 2014.

Lourey, M. and Trull, T. W.: seasonal nutreint depletion and carbon export in the subantarctic and polar frontal zones of the Southern Ocean, J. Geophys. Res. Oceans, 106, 31463-31487, 2001.

Lourey, M. J., Trull, T. W., and Sigman, D. M.: Sensitivity of $\delta^{15} \mathrm{~N}$ of nitrate, surface suspended and deep sinking particulate nitrogen to seasonal nitrate depletion in the Southern Ocean, Global Biogeochem. Cy., 17, 1081, doi:10.1029/2002GB001973, 2003.

Marshall, J. and Speer, K.: Closure of the meridional overturning circulation through Southern Ocean upwelling, Nat. Geosci., 5, 171-180, doi:10.1038/ngeo1391, 2012.

Martin, J. M. and Fitzwater, S. E.: Iron deficiency limits phytoplankton growth in the north-east Pacific subarctic, Nature, 331, 341-343, 1988.

Martinez-Garcia, A., Sigman, D. M., Ren, H., Anderson, R. F., Straub, M., Hodell, D. A., Jaccard, S. L., Eglinton, T. I., and Haug, G. H.: Iron Fertilization of the Subantarctic Ocean During the Last Ice Age, Science, 343, 1347-1350, 2014.

Michaels, A. F., Olson, D., Sarmiento, J., Ammerman, J. W., Fanning, K. A., Jahnke, R. A., Knap, A. H., Lipschultz, F., and Prospero, J. M.: Inputs, losses and transformations of nitrogen and phosporus in the pelagic North Atlantic Ocean, Biogeochemistry, 35, 181-226, 1996.

Minas, H. J. and Minas, M.: Net community production in "High Nutrient-Low Chlorophyll" waters of the tropical and antarctic oceans: grazing versus iron hyopthesis, Oceanol. Acta, 15, 145162, 1992.

Moore, C. M., Hickman, A. E., Poulton, A. J., Seeyave, S., and Lucas, M. I.: Iron-light interactions during the CROZet natural iron bloom and EXport experiment (CROZEX): II - Taxonomic responses and elemental stoichiometry, Deep-Sea Res. Part II, 54, 2066-2084, 2007.

Park, Y.-H., Durand, I., Kestenare, E., Rougier, G., Zhou, M., d' Ovidio, F., Cotté, C., and Lee, J.-H.: Polar Front around the Kerguelen Islands: An up-to-date determination and associated circulation of surface/subsurface waters, J. Geophys. Res. Oceans, 119, 6575-6592, doi:10.1002/2014JC010061, 2014.

Planquette, H., Statham, P. J., Fones, G., Charette, M. A., Moore, C. M., Salter, I., Nédélec, F. H., Taylor, S. L., French, M., Baker, A. R., Mahowald, N., and Jickells, T. D.: Dissolved iron in the 
vicinity of the Crozet islands, Southern Ocean, Deep-Sea Res. Pt. II, 54, 1999-2019, 2007.

Quéroué, F., Sarthou, G., Planquette, H. F., Bucciarelli, E., Chever, F., van der Merwe, P., Lannuzel, D., Townsend, A. T., Cheize, M., Blain, S., d'Ovidio, F., and Bowie, A. R.: High variability of dissolved iron concentrations in the vicinity of Kerguelen Island (Southern Ocean), Biogeosciences Discuss., 12, 231-270, doi:10.5194/bgd-12-231-2015, 2015.

Redfield, A. C., Ketchum, B. H., and Richards, F. A.: The influence of organism on the composition of seawater, in: The Sea, edited by: Hill N. M., New York., 1963.

Rembauville, M., Salter, I., Leblond, N., Gueneugues, A., and Blain, S.: Export fluxes in a naturally fertilized area of the Southern Ocean, the Kerguelen Plateau: seasonal dynamic reveals long lags and strong attenuation of particulate organic carbon flux (Part 1), Biogeosciences Discuss., 11, 17043-17087, doi:10.5194/bgd-11-17043-2014, 2014.

Sarmiento, J. L. and Orr, J. C.: Three-dimensional simulations of the impact of Southern Ocean nutrient depletion on atmospheric $\mathrm{CO}_{2}$ and ocean chemistry, Limnol. Oceanogr., 36, 1928-1950, 1991.

Sarmiento, J. L., Gruber, N., Brzezinsky, M. A., and Dunne, J. P.: High-latitude controls of thermocline nutrients and low latitude biological productivity, Nature, 427, 56-60, 2004.

Sarthou, G., Timmermans, K. R., Blain, S., and Treguer, P.: Growth physiology and fate of diatoms in the ocean: a review, J. Sea Res., 53, 25-42, 2005.

Sigman, D. M. and Boyle, E. A.: Glacial/interglacial variations in atmospheric carbon dioxide, Science, 407, 859-869, 2000.
Smetacek, V., Klaas, C., Strass, V. H., Assmy, P., Montresor, M., Cisewski, B., Savoye, N., Webb, A., d' Ovidio, F., Arrieta, J. M., Bathmann, U., Bellerby, R., Berg, G. M., Croot, P., Gonzalez, S., Henjes, J., Herndl, G. J., Hoffmann, L. J., Leach, H., Losch, M., Mills, M. M., Neill, C., Peeken, I., Röttgers, R., Sachs, O., Sauter, E., Schmidt, M. M., Schwarz, J., Terbrüggen, A., and Wolf-Gladrow, D.: Deep carbon export from a Southern Ocean iron-fertilized diatom bloom, Nature, 487, 313-319, 2012.

Trull, T. W., Davies, D. M., Dehairs, F., Cavagna, A.-J., Lasbleiz, M., Laurenceau, E. C., d' Ovidio, F., Planchon, F., Leblanc, K., Quéguiner, B., and Blain, S.: Chemometric perspectives on plankton community responses to natural iron fertilization over and downstream of the Kerguelen Plateau in the Southern Ocean, Biogeosciences Discuss., 11, 13841-13903, doi:10.5194/bgd11-13841-2014, 2014.

Wagener, T., Guieu, C., Losno, R., Bonnet, S., and Mahowald, N.: Revisiting atmospheric dust export to the southern hemisphere ocean: biogeochemical implication, Global Biogeochem. Cy., 22, doi:10.1029/2007GB002984., 2008.

Wang, X., Matear, R. J., and Trull, T. W.: Nutrient utilization ratios in the Polar Frontal Zone in the Australian sector of the Southern Ocean: A model., Global Biogeochem. Cy., 17, 1009, doi:10.1029/2002GB001938, 2003.

Weber, T. S. and Deutsch, C.: Ocean nutrient ratios governed by plankton biogeography, Nature, 467, 550-554, 2010.

Zamora, L. M., Prospero, J. M., Hansell, D. A., and Trapp, J. M.: Atmospheric P deposition to the subtropical North Atlantic: sources, properties, and relationship to $\mathrm{N}$ deposition, J. Geophys. Res.-Atmos., 118, 1546-1562, 2013.

Zhou, M., Zhu, Y., d'Ovidio, F., Park, Y.-H., Durand, I., Kestenare, E., Sanial, V., Van-Beek, P., Queguiner, B., Carlotti, F., and Blain, S.: Surface currents and upwelling in Kerguelen Plateau regions, Biogeosciences Discuss., 11, 6845-6876, doi:10.5194/bgd-116845-2014, 2014. 